\title{
Asymptomatic bacteriuria in pregnant women attending Boo-Ali Hospital Tehran Iran: Urine analysis vs. urine culture
}

\author{
Mina Etminan-Bakhsh ${ }^{1}$, Sima Tadi ${ }^{1}$, Roksana Darabi ${ }^{1}$
}

${ }^{1}$ M.D Gynecologist, Associate Professor, Department of Obstetrics and Gynecology, Islamic Azad University, Tehran Medical Sciences Branch, Tehran, Iran

Type of article: Original

\begin{abstract}
Background: Asymptomatic bacteriuria is one of the common problems in pregnancy. Asymptomatic bacteriuria is associated with pyelonephritis, preterm labor and low birth weight infants. The physiological and anatomical changes in pregnancy facilitate urinary tract infection (UTI) during pregnancy. Several tests are available for diagnosis of asymptomatic bacteriuria. The urine culture is a gold standard diagnostic test for asymptomatic bacteriuria but it is expensive and time-consuming. Screening methods may be useful in detecting high-risk pregnant women for asymptomatic bacteriuria.

Objective: The aim of the present study was to compare urine analysis as a rapid screening test to urine culture in diagnosis of asymptomatic bacteriuria.

Methods: A total of 123 pregnant women attending the obstetrics clinic of Boo-Ali hospital in Tehran, Iran from March 2013 to September 2014 were included in the present diagnostic cross-sectional study. One hundred twenty three mid-stream urine samples were inoculated into cultures and were processed by dipstick (nitrite test and leucocyte esterase test) and microscopic pus cell count. The sensitivity, specificity, positive predictive value and negative predictive value of nitrite test, leucocyte esterase test and microscopic pus cell count were compared with urine culture in diagnosis of asymptomatic bacteriuria by using SPSS version 19.

Results: Of 123 urine samples, significant asymptomatic bacteriuria $\left(\geq 10^{4} \mathrm{cfu} / \mathrm{Ml}\right)$ was detected in $8(6.5 \%)$ subjects. The sensitivity and specificity of nitrite test were $37 \%$ and $100 \%$ respectively. The sensitivity of pus cell count alone and leucocyte esterase test alone were $100 \%$ but the specificity of them were $64 \%$ and $65 \%$ respectively. We found high negative predictive value by Pus cell count and the leucocyte esterase test (100\%) and low positive predictive value by them ( $16 \%$ and $17 \%$ respectively).

Conclusion: Urine culture is the most useful test for diagnosis of asymptomatic bacteriuria. None of our screening tests had a sensitivity and specificity of $100 \%$, whereas we can only refer the pregnant women with positive leucocyte esterase test and significant pyuria to the urine culture.

Keywords: Asymptomatic Bacteriuria; Pregnancy; Urine culture; Screening tests
\end{abstract}

\section{Introduction}

During pregnancy, the urinary tract will endure an intense physiological and anatomical change that facilitates the development of both symptomatic and asymptomatic bacteriuria in women (1). Physiological increase in plasma volume during pregnancy, decreases urine concentration by up to $70 \%$, subsequently developing glucosuria in pregnant women, which causes bacterial growth in the urine $(2,3)$. Asymptomatic bacteriuria refers to the presence of bacteria in the urine. The urine culture reveals a significant growth of pathogens that is greater than 105 bacteria/ml, but without the patient presenting UTI symptoms (4). The prevalence of asymptomatic bacteriuria in pregnant women varies $1.6-86 \%(5-11)$. It is calculated that $30-40 \%$ of untreated pregnant women who have asymptomatic bacteriuria will eventually develop acute pyelonephritis in late pregnancy. Pyelonephritis is associated

\section{Corresponding author:}

Associate Professor Dr. Roksana Darabi, Department of Obstetrics and Gynecology, Islamic Azad University, Tehran Medical Sciences Branch, Tehran, Iran.

Tel: +98.2122566336, Fax: +98.2122549029, Email: roksana_darabi@yahoo.com

Received: October 19, 2016, Accepted: June 26, 2017, Published: November 2017

iThenticate screening: June 29, 2017, English editing: October 12, 2017, Quality control: October 15, 2017

This article has been reviewed / commented by Three experts

(C) 2017 The Authors. This is an open access article under the terms of the Creative Commons Attribution-NonCommercialNoDerivs License, which permits use and distribution in any medium, provided the original work is properly cited, the use is non-commercial and no modifications or adaptations are made. 
with significant morbidity for both mother and fetus during pregnancy. Therefore, it is imperative that exact screening and treatment of bacteriuria, are carried out regardless of symptoms, in order to avoid additional complications (5). On the other hand, some studies showed no reliable evidence supports routine screening for ASB in pregnant women and a routine ASB screen-and-treat policy may not result in a considerable gain in health outcomes (12). Several tests are available for diagnosis of asymptomatic bacteriuria. The urine culture is a gold standard diagnostic test for asymptomatic bacteriuria, but it is expensive and time-consuming (approximately 48 hours). Some screening methods such as leukocyte esterase test, nitrate test, and pus cell count (as urine analysis) may be useful in detecting high-risk pregnant women for UTI. Urine analysis is an inexpensive, less timeconsuming test and needs limited expertise. However, the screening methods are useless in evaluating the quantity of infection. Up to this day, there are conflicting opinions about the best screening test (13-20). The aim of the present study is to compare the diagnostic accuracy of leukocyte esterase test, nitrate test and pus cell count as a rapid screening test of asymptomatic bacteriuria in pregnant women.

\section{Material and Methods}

\subsection{Research design and participants}

This cross-sectional study was conducted on 123 pregnant women who attended Boo-Ali hospital affiliated to Islamic Azad University in Tehran, Iran from March 2013 to September 2014. This study is approved by the ethical committee of Islamic Azad University, Tehran Medical Sciences Branch. All pregnant women attending the obstetrics clinic of Boo-Ali hospital were included in present study if they were pregnant with varying gestational age without any symptoms and signs of UTI, without any intake of antibiotics during the past week and without genitourinary complaints. Women with vaginal bleeding during specimen collection were excluded from study.

\subsection{Data Collection}

In the laboratory of Boo-Ali Hospital, A "Clean Catch" morning (mid-stream) urine sample was collected in a sterile universal bottle after giving proper instruction to collect a sample to every woman. Samples were labeled and transported to the microbiology laboratory of Boo-Ali Hospital and were analyzed within one hour. All specimens cultured and were tested by a dipstick strip and were examined by microscope.

\subsection{Urine Culture}

A standard loop full of the urine sample was inoculated into duplicate plates of MacConkey agar and blood agar. The plates were incubated aerobically at $37^{\circ} \mathrm{C}$ for $24 \mathrm{~h}(21)$. Then the plates were examined for bacterial growth macroscopically and microscopically. After the bacterial colonies were counted, they were multiplied by 100 in order to give an estimate of the number of bacteria present per milliliter of urine. Because pyelonephritis develops in some women despite colony counts of only 20,000 to 50,000 organisms $/ \mathrm{mL}$, colony counts equal to or more than $10,000 \mathrm{cfu} / \mathrm{Ml}$ were considered as significant bacteriuria (2).

\subsection{Other laboratory methods and data analysis}

Urine samples were mixed and aliquots centrifuged at $5000 \mathrm{rpm}$ for $5 \mathrm{~min}$. The deposits were examined using both $\mathrm{x} 10$ and $\mathrm{x} 40$ objectives. The presence of at least 6 white blood cells/ $\mathrm{mm}^{3}$ was regarded as significant pyuria. The uncentrifuged urine samples were tested by a dipstick strip (Uriscan Co.). The appearance of a pink color indicates the presence of nitrate reducing enzymes that reduce nitrate to nitrite. The nitrate reducing enzyme is produced by most of the urinary tract pathogens. A positive value for a nitrate reductase test was nitrite $(+)$. Inflammatory cells produce leucocyte esterase (LE). The leucocyte esterase reacts with dipstick strip impregnated chloroacetate, and causes a color change. Violet color was considered as leucocyte esterase positive. In our study, positive value for a leucocyte esterase test was 1 plus or more. The nitrite test, pus cell count and leucocyte esterase test (sensitivity, specificity, positive predictive value and negative predictive value) were compared with urine culture in diagnosis of asymptomatic bacteriuria by using SPSS version 19 software.

\section{Results}

A total of 123 pregnant women were included in this study. The mean age of the pregnant women was $28 \pm 5.14$ (range, 16-38 years). Significant asymptomatic bacteriuria ( $\left.\geq 10^{4} \mathrm{cfu} / \mathrm{Ml}\right)$ was detected in $8(6.5 \%)$ subjects. The most common organism was E. coli in $5(62.5 \%)$ samples followed by Klebsiella in $2(25 \%)$ samples and Proteus in $1(12.5 \%)$ sample. The nitrite test could detect $3 / 8(37.5 \%)$ culture positive subjects. The nitrite test had a sensitivity of $37 \%$ and specificity of $100 \%$, which was the least sensitive test. The LE test detected $8(100 \%)$ culture positive subjects and among negative urine culture cases the LE test was positive in 40 women and negative in 75 women. In this study, the LE test had a sensitivity of $100 \%$ and specificity of $65 \%$. The significant pyuria detected $8(100 \%)$ 
culture positive subjects. Among the women with negative urine cultures, the significant pyuria detected 41 subjects as positive (false positive). In our study pyuria had a sensitivity of $100 \%$ and specificity of $64 \%$. The results if this study, sensitivity, specificity, positive predictive value and negative predictive value of screening methods are shown in Table 1 and Table 2.

Table 1. Statistical values for nitrite test, leucocyte esterase test and pus cell count

\begin{tabular}{|l|l|l|l|l|l|}
\hline Test & True positive & True negative & False positive & False negative & Total number of cases \\
\hline Nitrite & 3 & 115 & 0 & 5 & 123 \\
\hline leucocyte esterase & 8 & 75 & 40 & 0 & 123 \\
\hline Pus cell count & 8 & 74 & 41 & 0 & 123 \\
\hline
\end{tabular}

Table 2. Sensitivity, specificity, predictive value for various screening tests

\begin{tabular}{|l|l|l|l|l|}
\hline Test & Sensitivity\% & Specificity $\%$ & Positive predictive value $\%$ & Negative predictive value $\%$ \\
\hline Nitrite & 37.5 & 100 & 100 & 96 \\
\hline leucocyte esterase & 100 & 65 & 17 & 100 \\
\hline Pus cell count & 100 & 64 & 16 & 100 \\
\hline
\end{tabular}

\section{Discussion}

In this study, the sensitivity of nitrite test was 37.5\% which is lesser than other studies such as that by Mukherjee et al. (71.42\%) and Mundhada et al. (86.95\%) (13). A similar result was seen by Mambatta et al. (23.31\%) (14). The nitrite test demonstrated a high specificity $(100 \%)$, positive predictive value $(100 \%)$ and negative predictive value (96\%) which is in agreement with Fatima Ansari et al. and others $(11,13,14,15,17)$, but PPV which was found in a study by Thakre et al. was lower (16). In our study all of the organisms of culture-positive patients were of the gramnegative variety and urine samples had enough bladder incubation time (morning sample), thus absence or dilution of dietary nitrate in urine, may be the reasons for low sensitivity of nitrite test. In our study, the LE test had a sensitivity of $100 \%$, which is higher than other studies $(71.42 \%, 61.7 \%, 48.5 \%$ and $20.8 \%) 14,15,17,20$. In this study, positive value for an LE test was 1 plus or more, that may vary among different studies, it may be the cause of high sensitivity of the LE test. Despite Mukherjee et al., we did not have a false negative LE test. False negative findings may result from high level of protein and vitamin $\mathrm{C}$ in urine. The LE test had a specificity of $65 \%$, lower than Mukherjee et al. (92\%). The specificity of the LE test was lower than the nitrite test (100\%). Based on our study, significant pyuria demonstrated a high sensitivity $(100 \%)$ and negative predictive value (100\%), which is higher than Mukherjee et al. (42.85\%, 94.78\%), Thakre et al. (72.41\%, 96.96\%) and Mundhada (Sensitivity: $63.04 \%$ ). Low sensitivity in these studies may be caused by the fact that they used uncentrifuged urine, but based on a study by R Kurup and M Leich, we used centrifuged urine for WBCs because both methods (centrifuged urine \& uncentrifuged urine) showed a good correlation between urinary sedimentation with the exception of white blood cells (22). Our study found that the pyuria had low specificity (64\%) and low positive predictive value (16\%) similar to the leucocyte esterase test. Other studies $(16,17)$ showed much higher specificity of pyuria than our study $(94.47 \%, 95.19 \%)$. Because pyuria is seen in other diseases (genitourinary infections), and is not specific to UTI, this finding maybe explained by presence of genitourinary infections in women without any complaint.

\section{Conclusions}

Urine culture is the most useful test for diagnosis of asymptomatic bacteriuria. We found that the nitrite test had low sensitivity for the screening of asymptomatic bacteriuria. The leucocyte esterase test and significant pyuria with low specificity, had high sensitivity and high negative predictive value. We had no single test with $100 \%$ sensitivity and specificity. Thus we can only refer the pregnant women with positive leucocyte esterase test and significant pyuria to the urine culture. Due to our small sample size, further studies with larger number of samples are recommended.

\section{Acknowledgments:}

We are grateful to the laboratory of Boo-Ali Hospital for their cooperation. This study was supported by Islamic Azad University, Tehran Medical Sciences Branch, Tehran, Iran. The funding organizations had no role in the design or conduct of the study.

\section{Conflict of Interest:}

There is no conflict of interest to be declared.

Authors' contributions:

All authors contributed to this project and article equally. All authors read and approved the final manuscript. 


\section{References:}

1) Begum N. Clinical profile of urinary tract infection in pregnancy. Mymensingh Med J. 1992; 1: 6-10.

2) Lucas MJ, Cunningham FG. Urinary tract infection in pregnancy. Clinical Obstet Gynaecol.1993; 36: 85568. doi: 10.1097/00003081-199312000-00009.

3) Patterson TF, Andrriole VT. Bacteriuria in pregnancy. Infect Dis Clin North Am. 1987; 1: 807-22. PMID: 3333660.

4) Gilbert DN, Moelleving RC Jr, Eliopoulos GN, Sande NA. Sanford guide to Antimicrobial therapy. 32 nd ed. Hyde Park, Vermont: Antimicrob Therapy, Inc; 2005: 22-3.

5) Ahmad S, Shakooh S, Salati SA, Muniem A. Prevalence of asymptomatic bacteriuria among pregnant women in Kashmir. Sri Lanka J Obstet Gynaecol. 2011; 33: 158-62.

6) Etminan-Bakhsh M, Darabi R, Tadi S, Mohit M. Frequency Survey of Asymptomatic Bacteriuria in Pregnant Women Attending Boo-Ali Hospital, Tehran. Galen Medical Journal. 2015; 4(4): 159-63.

7) Olusanya O, Ogunledum A, Fakoya TA. Asymptomatic significant bacteriuria among pregnant and nonpregnant women in Sagamu, Nigeria. WAJM. 1993; 12(1): 27-33.

8) Akerele P, Abhuliren F, Okonofua J. Prevalence of asymptomatic bacteriuria among pregnant women in Benin City, Nigeria. J Obstet Gynaecol. 2001; 21(2): 141-4. doi: 10.1080/01443610020026038. PMID: 12521882 .

9) Gabre-Selassie S. Asymptomatic bacteriuria in pregnancy; epidemiological clinical and microbiological approach. Ethiop Med J. 1998; 36: 185-92.

10) Daneshyar E, Mosavibahar SH, Alikhani MY. Association Between Asymptomatic Bacteriuria and Some demographic variables in pregnant women Refered to Health Centers Affilited to Hamadan University of Medical Sciences. Scientific Journal of Ilam University of Medical Sciences. 2010: 53-60.

11) Fatima Ansari Q, Rajkumari A. Prevalence of asymptomatic bacteriuria and associated risk factors among antenatal women attending a tertiary care hospital. Journal of Medical \& Allied Sciences. 2011; 1 (2): $74-8$.

12) Angelescu K, Nussbaumer-Streit B, Sieben W, Scheibler F, Gartlehner G. Benefits and harms of screening for and treatment of asymptomatic bacteriuria in pregnancy: a systematic review. BMC Pregnancy and Childbirth. 2016; 16: 336. doi: 10.1186/s12884-016-1128.

13) Mundhada SG, Ingole KV, Bhise MP, Shaikh SV. Evaluation of different screening tests for detection of Urinary Tract Infection in pregnant women attending the antenatal clinic. Int J Curr Microbial App Sci. 2016; 5(4): 772-7.

14) Mambatta AK, Jayarajan J, Rashme VL, Harini S, Menon S, Kuppusamy J. Reliability of dipstick assay in predicting urinary tract infection. J Family Med Prim Care. 2015; 4(2): 265-8.

15) Jayalakshmi J, Jayaram VS. Evaluation of various screening tests to detect asymptomatic bacteriuria in pregnant women. Indian J Pathol Microbiol. 2008; 51(3): 379-81. doi: 10.4103/0377-4929.42516. PMID: 18723963.

16) Thakre SS, Dhakne SS, Thakre SB, Thakre AD, Ughade SM, Kale P. Can the griess nitrite test and a urinary pus cell count of $\geqslant 5$ cells per micro litre of urine in pregnant women be used for the screening or the early detection of urinary tract infections in rural india? J Clin Diagn Res. 2012; 6(9): 1518-22. doi: 10.7860/JCDR/2012/4565.2547.

17) Mukherjee K, Golia S, Vasudha CL, Babita, Bhattacharjee D, Chakroborti G. A study on asymptomatic bacteriuria in pregnancy: prevalence, etiology and comparison of screening methods. Int J Res Med Sci. 2014; 2(3): 1085-91. doi: 10.5455/2320-6012.ijrms20140886.

18) Macejko AM, Schaeffer AJ. Asymptomatic bacteriuria and symptomatic urinary tract infections during pregnancy. Urol Clin North Am. 2007; 34: 35-42. doi: 10.1016/j.ucl.2006.10.010. PMID: 17145359.

19) Bachman JW, Heise RH, Naessone JM, Timmerman MG. A study of various tests to detect asymptomatic urinary tract infections in an obstetric population. JAMA. 1993; 270: 1971-4. doi: 10.1001/jama.1993.03510160089035. PMID: 8411555.

20) Mokube MN, Atashili J, Halle-Ekane GE, Ikomey GM, Ndumbe PM. Bacteriuria amongst pregnant women in the Buea health district, Cameroon: prevalence, predictors, antibiotic susceptibility patterns and diagnosis. PLOS One. 2013; 8(8): e71086. doi: 10.1371/journal.pone.0071086. PMID: 23976983, PMCID: PMC3745459.

21) Michael L.Wilson,Loretto Gaido Laboratory Diagnostic of Urinary Tract Infection in Adult Patients.Clinical Infectious Disease, 2004; 38(8): 1150-1155. doi: 10.1086/383029, PMid: 15095222

22) Kurup R, Leich M. Comparison of urine analysis using manual sedimentation methods. West Indian Med J. 2012; 61(3): 240. doi: 10.7727/wimj.2011.035. PMID: 23155980. 